\title{
Produksi Kritik Iklan Politik melalui Memes
}

\author{
Dyon Liuswanto, Sinta Paramita \\ dyon.915150066@stu.untar.ac.id,sintap@fikom.untar.ac.id
}

Fakultas Ilmu Komunikasi Universitas Tarumanagara

\begin{abstract}
Politcal advertisings are advertising that have political contents, mixed inside. These type of political messages are often used for campaign purposes. Nurhadi and Aldo, came to critic the political campaigns of both President and vice president candidate, by using social media especially facebook as a media. Based on goals - planning - action theory, the use of meme can be seen as part of the plan to criticize. Meme was seen as a shape of dynamic message where instead of the sender, the reciever must interpret the meaning of the message. Virtual etnography was used as a method to analyze where foundings such as the goal of the message production was to influence people to be more wary of posts, they also used the fanpage as a means to learn about politics, may it be politics about the country, or internal politics.
\end{abstract}

Keywords: mass communication, meme, virtual etnography, goals - planning - action theory

\begin{abstract}
Abstrak
Iklan politik adalah sebuah iklan yang mengandung unsur politik didalamnya. Bentuk pesan politik ini digunakan untuk kampanye. Nurhadi dan Aldo hadir untuk mengkritik kampanye yang dilakukan pasangan calon presiden dan wakil presiden yang ada dengan menggunakan media sosial facebook sebagai media. Bedasarkan teori goals - planning - action, penggunaan meme itu sendiri dapat menjadi sebuah rencana yang digunakan untuk mengkritik. Meme dilihat sebagai sebuah bentuk penyampaian pesan yang dinamis dimana perlu interpretasi dari penerima pesan untuk mengerti isi dari meme itu sendiri. Etnografi virtual menjadi sebuah basis dalam pembahasan ini dimana ditemukan bahwa selain tujuan untuk mengubah persepsi seseorang agar menjadi lebih waspada terhadap post, mereka juga menggunakan fanpage ini sebagai sebuah sarana lain seperti pembelajaran terhadap situasi politik baik politik negara, maupun politik internal.
\end{abstract}

Kata kunci: komunikasi massa, meme, etnografi virtual, teori goals planning action

\section{Pendahuluan}

Menurut data dari Lembaga Ilmu Pengetahuan Indonesia, ada gejala yang sangat kuat tentang meningkatnya intoleransi politik menjelang pemilu 2019. Sebut saja $57.8 \%$ dari 1800 responden hanya memilih pemimpin jika mereka satu kelompok (dalam - konteks ini agama.), selain itu mereka akan secara aktif juga menyerang orang lain yang tidak satu pilihan dengan mereka. Sebagai contoh kasus beda pilihan presiden yang berujung maut di Kabupaten Sampang, Jawa Timur.

Menurut Wadipalapa (2015), meme culture adalah sebuah kegiatan gerakan politik. Meme dilihat sebagai sebuah respon alternatif dalam sebuah kritik dan protes atas komunikator politik. Menurut Murkarom (dalam Tamburian, 2018), komunikasi politik adalah komunikasi yang diarahkan kepada pencapaian suatu pengaruh, sehingga masalah yang dibahas oleh kegiatan komunikasi ini dapat mengikat semua 
warga. Menurut Vivian (dalam Vinessa dan Kusniadji, 2018), komunikasi massa yaitu proses penggunaan sebuah media massa untuk mengirimkan pesan kepada audien yang luas untuk tujuan memberi informasi, menghibur, atau membujuk.

Melihat perkembangan ini pun, maka hadirlah akun Nurhadi - Aldo. Sebuah akun calon presiden dan wakil presiden fiktif yang sering melakukan post yang berisi tentang berbagai kritik mengenai beberapa hal yang terjadi di Indonesia, terutama tentang berbagai kegiatan politik yang ada disana. Kritik yang dilontarkan dalam post tersebut berupa candaan yang tidak pantas dan bersifat komedi. Peneliti melakukan penelitian ini untuk melihat cara akun ini bekerja (mencari alasan mengapa mereka melakukan post, rencana mereka, dan sebagainya).

Teori yang digunakan yakni goals - planning - action, sebuah teori yang dikemukakan oleh James Dillard (2015) mengenai produksi pesan. Dalam produksi pesan diperlukan sebuah tujuan, di mana tujuan tersebut akan kemudian berpengaruh pada rencana yang dibuat. Dalam pembahasan rencana, terdapat empat hal yang harus diperhatikan yaitu expliciteness, argumen, dominansi, dan kontrol. Setelah rencana tersebut matang, barulah dilakukan aksi, yaitu pengiriman pesan.

\section{Metode Penelitian}

Penelitian ini menggunakan metode kualitatif. Menurut Yusuf (2015) penelitian kualitatif adalah strategi yang menekankan pada pencarian makna, pengertian, konsep, karakteristik, gejala, simbol, maupun deskripsi tentang suatu fenomena; fokus dan multi metode, bersifat alami dan holistik; mengutamakan kualitas, menggunakan beberapa cara, serta disajikan secara naratif. Sedangkan metode yang digunakan adalah etnografi lebih tepatnya etnografi virtual sebagai strategi penelitian. Nasrullah (2017) menyatakan bahwa, etnografi secara sederhana adalah peninggalan budaya yang berasal dari suatu masyarakat. Virtual menyangkut lokasi dari suatu penelitian etnografi yaitu perbedaan lokasinya yang berarti internet.

Subjek dari penelitian adalah akun facebook Nurhadi dan Aldo, dan objek penelitian adalah post yang ada di akun facebook Nurhadi dan Aldo itu sendiri. Pada tanggal 22 Mei, akun tersebut berganti konsep. Periode observasi adalah 17 Desember 2018 sampai 21 Mei 2019. Peneliti menggunakan non - participant observation dimana penulis hanya melihat dan mengambil data saja yang ada di dalam akun facebook Nurhadi dan Aldo untuk data primer, sedangkan untuk data sekunder yang digunakan adalah berbagai pernyataan-pernyataan yang dikemukakan oleh akun fanpage Nurhadi - Aldo. Oleh karena itu, untuk medapatkan data tersebut, penulis memutuskan untuk melakukan wawancara dengan pihak yang cocok yaitu berbagai pengguna facebook yang mengikuti (ada fitur follow di facebook) fanpage tersebut.

Penulis menggunakan model Miles dan Huberman (dalam Yusuf, 2015) sebagai proses analisa data. Model ini sering disebut dengan model alir. Didalam model ini ada 3 tahap dalam menganalisa data sebagai berikut: Proses pemilihan, pemokusan, penyederhanaan, dan pentransformasian data yang sudah terkumpul. Reduksi data diperlukan untuk mempertajam, memilih, memfokuskan, membuang, dan mengorganisasikan data dalam satu cara, agar kesimpulan akhir dapat dibuat. 
Display yang dimaksudkan adalah kumpulan informasi yang telah tersusun sehingga bisa di ambil kesimpulannya. Biasanya berbentuk teks naratif sebuah kejadian Kesimpulan ditarik setelah semua data telah diolah (direduksi dan terdisplay) dengan baik. Jika ada perbedaan atau terasa kurang maka data kemudian diolah lagi dari awal.

\section{Hasil Temuan dan Diskusi}

Dalam teori goals - planning - action disebutkan bahwa pembuatan sebuah pesan memerlukan tujuan, perencanaan, lalu aksi pengiriman pesan. Dalam teori tersebut, tujuan dibagi menjadi dua yaitu tujuan primer dan sekunder. Tujuan primer dari akun Nurhadi dan Aldo adalah mempengaruhi, tujuan ini memang sesuai dengan apa yang diinginkan oleh tim Nurhadi dan Aldo dimana mereka ingin agar konsumsi meme yang mereka buat oleh pengguna media sosial akan mempengaruhi mereka agar mereka semakin pandai dalam menghadapi sebuah pesan, bahkan isu - isu sensitif. Sedangkan tujuan sekunder adalah pendekatan dengan para pengguna media sosial agar menjadi lebih akrab.

Dalam mencapai tujuan tersebut, dibutuhkan sebuah rencana. Pada pembuatan setiap post, tim Nurhadi dan Aldo sudah memiliki sistem khusus yaitu seperti berikut:

1. Pada awalnya dicari dulu isu politik yang memang sedang hangat, bisa saja berupa sebuah isu agraria, atau berbagai isu lain yang memang sedang hangat saat itu. Setelah itu, proses pembuatan meme dijalankan.

2. Diawali dengan pengumpulan berbagai ide mengenai meme tentang suatu isu tersebut. Ide tersebut kemudian dibahas dengan sesama tim pengurus untuk melihat apa yang masih dibutuhkan atau jika memang sudah bagus.

3. Ide - ide tersebut kemudian diberikan kepada penyunting. Ada dua jenis penyunting dalam hal ini yaitu copywriter yang tugas hanya melakukan koreksi baik secara tanda baca maupun susunan kalimat. Penyunting yang lain adalah editor yang memang mengatur secara desain apakah meme tersebut sudah bagus atau belum.

4. Setelah dirasa cukup, post kemudian diberikan kepada yang lain untuk diminta pendapatnya apakah sudah cukup bagus atau masih kurang memiliki dampak.

5. Untuk umpan balik, mereka tidak terlalu memperhatikan, kecuali memang bisa timbul ide - ide baru.

Lalu mengapa menggunakan meme sebagai bentuk pesan mereka? meme digunakan karena dipercaya sebagai suatu simbol generasi sekarang. Ditambah bahwa meme adalah suatu hal yang dapat digunakan untuk bereksplorasi berbagai pesan dengan pembuatan metafor dengan cara menggabungkan beberapa gambar, kata, vidio, dan sebagainya. Mereka mempercayai bahwa penggunaan meme, bisa melatih kemampuan pengguna media sosial agar semakin wawas dalam melihat suatu fenomena tertentu.

Pesan yang disampaikan kemudian dibalut dengan berbagai nuansa mesum dan kasar. Untuk menemukan beberapa nada mesum di akun ini, cukup seperti contohnya saja melihat username dari fanpage Nurhadi dan Aldo ini, yaitu @Dildoforindonesia.

Dalam perencanaan, terdapat empat faktor yang diperhatikan dalam pembuatan pesan, yaitu eksplisit, argumen, dominansi, dan kontrol. Hal yang paling mudah dibahas adalah kontrol, kontrol yang dimaksud disini adalah kekuatan untuk 
mengatur timbal balik yang diterima. Dalam mengatur timbal balik tersebut, harus dilihat kembali pada sifat komunikasi massa itu sendiri. Seperti diungkapkan Ngalimun (2017), salah satu sifat komunikasi massa adalah sifatnya yang terbuka dan tersebar secara luas yang berarti bahwa dalam komunikasi massa, penerima pesannya itu orangnya banyak, beragam, dan anonim. Tercermin dalam grafik timbal balik. Tim Nurhadi dan Aldo kurang memiliki kemampuan untuk mengontrol umpan balik tersebut.

Kedua adalah eksplisit. Kejelasan pesan yang ingin disampaikan meamng sengaja dibuat tidak terlalu jelas. Menurut mereka, salah satu kegunaan meme sebagai suatu media adalah sifatnya yang "cair, lunak, dinamis" yang dapat diartikan bahwa arti dari meme itu sendiri memang harus diinterpretasikan sesuai kemampuan penerima pesan itu sendiri.

Hal ketiga adalah dominansi. Dalam konteks ini, Nurhadi dan Aldo sebagai sebuah fanpage meletakkan diri mereka paling tidak di atas penerima pesan mereka.

Terakhir adalah argumen. Untuk membahas hal ini, perlu melihat post mengenai beberapa kebijakan yang mereka keluarkan. Dalam hal ini, biasanya kebijakan tersebut akan didukung oleh beberapa data yang menguatkan pesan tersebut.

Komponen yang terakhir adalah aksi. Setelah post dirasa matang dan siap diedarkan, maka kemudian post tersebut diedarkan ke masyarakat luas. Pesan kemudian dikirim ke media sosial, terutama facebook, twitter, dan instagram. Dalam media sosial sekarang, sudah dapat dilihat bagaimana umpan balik dari pengguna media sosial terhadap pesan yang dikirimkan.

Tabel 1 Data Umpan Balik Facebook

\begin{tabular}{ccccccc} 
Bulan & Like & Comment & Share & Jumlah post & $\begin{array}{c}\text { Rata - Rata } \\
\text { post }\end{array}$ & Catatan \\
\hline Desember & 2450 & 395 & 727 & 93 & 16 & $\begin{array}{c}\text { Dimulai pada } \\
\text { tanggal 17. }\end{array}$ \\
\hline Januari & 5365 & 696 & 847 & 117 & 3 & $\begin{array}{c}\text { Puncak } \\
\text { relevansi }\end{array}$ \\
\hline Februari & 2430 & 345 & 277 & 75 & 2 & - \\
\hline Maret & 1710 & 222 & 171 & 77 & 2 & - \\
\hline April & 3590 & 964 & 963 & 24 & 1 & $\begin{array}{c}\text { Sebelum tanggal } \\
15 \text {, hanya ada 2 } \\
\text { post }\end{array}$ \\
\hline Mei & 1658 & 314 & 145 & 26 & 1 & $\begin{array}{c}\text { Post sudah mulai } \\
\text { tidak rutin, } \\
\text { berakhir pada } \\
\text { tanggal 21 }\end{array}$
\end{tabular}

Sumber : observasi @dildoforindonesia 
Dalam penggambaran pada tabel, dapat terlihat bahwa besarnya umpan balik yang didapatkan akun fanpage Nurhadi dan Aldo di facebook ada peningkatan peminat pada bulan Desember dan Januari, lalu menurun sejak bulan Februari dan Maret, meningkat lagi saat April, lalu turun lagi saat bulan Mei.

Tabel tersebut juga menunjukkan bahwa adanya penurunan frekuensi post yang dilakukan oleh tim Nurhadi dan Aldo yaitu dimulai dari sekitar 6 post setiap hari pada bulan Desember, 3 post setiap hari pada bulan Januari, 2 post setiap hari pada bulan Februari dan Maret, sampai akhirnya hanya sekitar 1 post saja setiap hari sejak bulan April.

Lalu diantara semua post tersebut, manakah yang paling disukai? Dalam bulan April, post yang paling banyak disukai oleh pengguna facebook adalah hasil pilpres menurut mereka, dimana post tersebut mendapatkan 11.000 likes, 946 komentar, dan 6800 kali dibagikan kepada pengguna lain, sedangkan dalam bulan Januari, post yang paling disukai adalah post vidio yang berisi tentang mars atau lagu untuk partai mereka.

Bagaimana dengan tanggapan orang diluar pengguna facebook itu sendiri? Pihak KPU, menyatakan bahwa mereka merasa terinspirasi dengan adanya akun ini, untuk menyediakan informasi kepada masyarakat dengan lebih ada unsur humor didalamnya (Kompas.com, 8 Januari 2019). Sedangkan pihak Bawaslu, menyatakan bahwa mereka biasa saja asalkan tim Nurhadi dan Aldo tidak melanggar hukum yang ada di Bawaslu, yaitu penghinaan terhadap salah satu calon presiden dan wakil presiden, jika ada laporan baru mereka tindaki. (kompas.com 9 Januari 2019). Sedangkan menurut Jokowi, (calon presiden nomor urut 1, serta presiden Indonesia) tentunya tidak ada rasa persaingan karena pasangan Nurhadi dan Aldo adalah calon fiktif.

Menurut tim admin Nurhadi dan Aldo, dalam mengelola akun Nurhadi dan Aldo ini, tidak melulu kritik yang diperhatikan didalamnya. Selain kritik, mereka juga secara tidak langsung belajar mengenai keadaan politik, baik dalam tingkat negara, maupun dalam tingkat sehari-hari sekalipun., tentunya mereka menganggap bahwa dengan mengelola akun ini, mereka bisa menjadi lebih dekat dengan pengguna facebook yang lainnya juga.

\section{Simpulan}

Nurhadi dan Aldo adalah sebuah akun fanpage di media sosial facebook yang mengkritisi iklan politik kedua pasangan calon presiden dan wakil presiden dengan cara menjadi sebuah calon fiktif. Dengan menjadi calon fiktif, kritik yang diberikan adalah berupa berbagai tindak kampanye - kampanye yang ada, seperti kebijakan kebijakan menurut mereka, kutipan - kutipan pendapat mereka, dan lainnya. Tujuan primer tim admin membuat akun ini adalah untuk mengedukasi masyarakat agar mereka lebih peka dengan post yang ada. Selain itu, tujuan sekundernya adalah untuk menjadi lebih dekat dengan pengguna media sosial.

Dalam perencanaan pembuatan post yang ada, ada sebuah prosedur dimana mereka mencari sebuah isu yang memang sedang panas, lalu mengolahnya kemudian menjadi sebuah meme. Meme yang dihasilkan mengandung nada-nada mesum dan kasar. Selain itu juga dalam sebuah post, mereka berhasil menempatkan diri mereka diatas penerima pesan mereka, dengan menggunakan argumen - argumen pendukung, dengan pesan yang tidak terlalu eksplisit sehingga dapat diinterpretasikan berbeda antara penerima pesan. 
Umpan balik yang diterima tidak terlalu diperhatikan oleh tim admin, namun umpan balik yang diterima, sangat besar saat pertama kali akun ini baru dibuat, dan terus menurun semenjak januari, dan hanya meningkat secara sesaat saat pemilu diadakan.

\section{Ucapan Terima Kasih}

Terima kasih penulis ucapkan kepada Fakultas Ilmu Komunikasi Tarumanagara, dan tim admin Nurhadi - Aldo sebagai narasumber penelitian ini. Dengan bantuan dari mereka maka penelitian ini dapat terselesaikan

\section{Daftar Pustaka}

Dillard, James. (2015). Goals - Plan - Action Theory. 26 Juni, 2019. Https://Researchgate.net

Farisa, Fitria Chusna (2019). Komentar KPU soal Fenomena Capres - Cawapres Fiktif Nurhadi - Aldo. 10 Juli, 2019. Kompas.com

Farisa, Fitria Chusna (2019). Soal Paslon Nurhadi-Aldo, Bawaslu Sebut itu "Fun". 10 Juli, 2019. Kompas.com

Nasrullah, Rusli. (2017). Etnografi Virtual : Riset Komunikasi, Budaya, dan Sosioteknologi di Internet. Bandung: Simbiosa Rekatama Media.

Nugroho, Puthut \& Kontributor Grobongan (2019). Kisah Nurhadi Capres Fiktif, Mulai dari Iseng April Mop Hingga Ketemu Jokowi (2019). 10 Juli 2019. Kompas.com

Nurhadi-Aldo: Dari Tukang Pijat Sampai Jadi Pasangan Capres Guyonan. (2019). Mei 5, 2019. https://www.bbc.com/indonesia/amp/trensosial-46751492

Setyanto, Yugih. \& Winduwati, Septia. \& Setyoutami, Lusia Savitri (2016). Perilaku Bermedia Remaja Awal Terhadap Sosok Idolanya (Kajian Parasosial Remaja Tingkat Awal sebagai efek Penggunaan Media Baru). Jakarta: Universitas Tarumanagara

Shifman, Limor (2014). Memes in Digital Culture. Massachusetts: Massachusettes Institute of Technology

Tamburian, D \& Budiman, J (2018). Komunikasi Politik Megawati Dalam Membangun Brand Image Partai. Koneksi, 2(2), 401 - 408, Desember 2018, DOI: http://dx.doi.org/10.24912/kn.v2i2.3916

Wadipalapa, R (2015). Meme Cult ure \& Komedi - Satire Politik : Kontestasi Pemilihan Presiden dalam Media Baru. Jurnal ilmu komunikasi,12(1), 1 - 18. Juni 25, 2019. Terarsip di http://ojs.uajy.ac.id/index.php/jik/article/view/440

Yusuf, Muri. (2015). Metode Penelitian Kuantitatif, Kualitatif, dan Penelitian Gabungan. Jakarta : Prenadamedia Group

Vanessa, V. \& Kusniadji, S (2018). Proses Komunikasi Melalui Kegiatan Event Adopt Don't Shop Guna Mengkampanyekan Kesadaran Masyarakat agar Menyayangi Binatang. Prologia, 2(2), 538 - 545. Desember 2018, DOI: http://dx.doi.org/10.24912/pr.v2i2.3742 
Vintoko, R. (2019, Mei 24). Pasca Pemilu 2019, Akun Nurhadi-Aldo Tiba-tiba Menghilang dan Sudah Berganti Nama. Mei 24, 2019. Line Today https://today.line.me/id/pc/article/Pasca+Pemilu+2019+Akun+Nurhadi+Aldo+ Tiba+tiba+Menghilang+dan+Sudah+Berganti+Nama-

nLXkOMutm_source=timeline\&utm_medium=post\&utm_campaign=timeline_ a\&openExternalBrowser $=1$ 